\title{
Duration of larval and pupal development stages of Aedes albopictus in natural and artificial containers*
}

\author{
Almério de Castro Gomes, Sabina Lea Davidson Gotlieb, Cristiano \\ C. de Azevedo Marques, Marcia Bicudo de Paula, Gisela Rita A.M. \\ Marques
}

\author{
Department of Epidemiology, School of Public Health, University of S. Paulo- \\ Brazil (A.C.G., S.L.D.G., M.B.P), Superintendency for the Control of Endemic \\ Diseases (SUCEN) - Brazil (C.C.A.M., G.R.A.M.M.)
}

\begin{abstract}
Aedes albopictus were reared in different containers: a tree hole, a bamboo stump and an auto tire. The total times from egg hatching to adult emergence were of $19.6,27.3$ and 37.5 days, respectlvely, according to the container. The first, second and third-instar larvae presented growth periods with highly similar durations. The fourth-instar larvae was longer than the others stages. The pupation tlme was longer than the fourth-instar larvae growth perlod. The temperature of the breeding sites studied, whlch was of $18^{\circ} \mathrm{C}$ to $22^{\circ} \mathrm{C}$ on average, was also taken into consideration. The mortality of the immature stages was analysed and compared as between the experimental groups; it was lower In the natural contalners than In the discarded tire. The average wing length of adult females emerging from tree hole was significantly larger $(p<0.05$ ) than that of those emerging from the tire.
\end{abstract}

Aedes, growth. Wing, growth.

Aedes albopictus is found from southeast Asian to several American countries, but its distribution within Brazilian territory is limited to five States. It has been introduced into some counties of the State of S. Paulo, Brazil since 1986 and commonly bites man and domestic animals (Brito et al. ${ }^{1}, 1986$; Gomes et al. $\left.{ }^{5}, 1993\right)$. Hawley ${ }^{6}(1988)$ and PAHO $^{13}$ (1989) reviewed the basic aspects of its biology and have thus made a considerable contribution.

In Tremembe County, during the first project, the larval habitat of this species presented different types and sizes, but few larvae were caught either in natural or artificial containers (Gomes et al. $\left.{ }^{4}, 1992\right)$; exception has to be made of tree holes whose volumes exceeded $200 \mathrm{ml}$. It is unknown whether this result was due to the fact that less oviposition occurred or to a very high rate of mortality. Artificial containers such as discarded tires and bamboo stumps are regarded as habitats of Ae albopictus. To estimate how long Ae albopictus larvae live, the container types, temperature and food supply must be taken into consideration.

Changes in physical conditions, environmental modifications, density and availability of food are factors correlated to the larval and pupal development of mosquitoes. Mori ${ }^{9}$ (1979) observed the influence of some feeding types and the larval density in relation to the rate of mortality and the adult body size of Ae. albopictus. On the other hand some papers argue that female body size may be an indicator of a characteristic that affects the mosquitoes' vectorial capacity (Landry et al. ${ }^{8}$, 1988 and $\mathrm{Nasci}^{11}, 1986$ ).

The present study was undertaken for the purpose of comparing development and mortality rates of immature stages in natural and artificial containers. The objective was to test whether a tree hole with more abundant food was a superior

\footnotetext{
'Supported by the "Fundação de Amparo à Pesquisa do Estado de São Paulo (FAPESP)" (Grant no. 90/3100.2) and the "Superintendência de Controle de Endemias (SUCEN)"

Reprints: Américo de Castro Gomes - Department of Epidemiology, School of Public Health

Av. Dr. Amaldo, 715 - 01246-904 - S. Paulo, SP - Brazil

The publication of this articles was supported by FAPESP. (Process 94/0500-0)

Submitted in 8.8.1994. Aproved in 11.22.1994.
} 
habitat to artificial containers with less food and to verify the extent of variation in adult body size as related to each experiment.

This research occurred during the autumn (20 April to 25 June 1993) when the microhabitats of Ae. albopictus still have an abundance of larvae (Gomes et al. ${ }^{4}, 1992$ ). The strain of Ae. albopictus used in this experiment was obtained from the periurban zone of Tremembé County, $S$. Paulo, Brazil. Some samples were brought to an insectary under controlled conditions. The females were put into a box of $30 \times 40 \times 30 \mathrm{~cm}$ after a blood-meal taken from a guinea-pig. The eggs obtained from them were maintained on a moist paper filter for three days at $20^{\circ} \mathrm{C}$ and $90 \%$ relative humidity before being hatched. All larvae that hatched within 12 hours were released into the respective experimental containers.

Experiment 1 - A tree hole in Delonix regia was chosen because it has been shown to be a very good breeding site for Ae. albopictus (Gomes et al. ${ }^{4}, 1992$ ). The hole was $25 \mathrm{~cm}$ deep and of $3,830 \mathrm{ml}$ capacity; the water was clear with some decayed material and low turbidity. It was filled with distilled water and the level was maintained during the experiment. The 80 first-instar larvae were released into a can that was $12 \mathrm{~cm}$ deep and $10 \mathrm{~cm}$ in diameter. It was made of metal-mesh and inserted into the tree hole, but a quarter of it was kept above the water level for the larvae to breathe.

Experiment 2 - A bamboo section $40 \mathrm{~cm}$ long and $12 \mathrm{~cm}$ in diameter had one liter of distilled water put into it. The water level was maintained during the experiment. The bamboo was placed in the shade of a tree. The open part of it was covered with a removable nylon-mesh to avoid oviposition by indigenous female mosquitoes. This experiment began with 83 first-instar larvae.

Experiment 3 - A section of a discarded car tire, which was obtained locally, was used. The tire was cleaned and dried before placing about one liter of distilled water into it. Ninety first-instar larvae of Ae. albopictus were put into it. The container was protected by a box with internal dimensions of $30 \times 35 \times 45 \mathrm{~cm}$ and covered by a nylon-mesh to avoid the entrance of any mosquitoes.

It was not possible to use the same number of larvae equally for the three experiments because of some deaths caused by the manipulation of the first-instar larvae. It was considered more important to ensure a same-age criterion for the three experiments. All three containers were kept under normal field conditions of temperature and light and no food was supplied.
Every day each container was inspected and all pupae and larvae found were registered according to the development stage. All dead immature forms were removed and registered by instar. In this way, the length of time required for the development of each cohort from hatching to pupation could be estimated. The numbers of resulting emergent adults were recorded and the wing and femur length of each female wasmeasured by Mori's method'.

A fixed thermometer was put into each container to measure the temperature, which was registered daily at $6.00 \mathrm{a} . \mathrm{m}$. and $1.00 \mathrm{p.m}$. This time schedule corresponded to the coolest and warmest environmental temperatures, respectively, in the Paraiba region. An indicator of the development time between stages was the weighted average, which was the number of individuals in each period (in days). The statistical analysis was performed by the least square method with a regression equation $\mathrm{M}=\mathrm{a} . \mathrm{n}$ (instar) $+\mathrm{b}$, where $M=$ mortality rate, using Lotus 123 software. "Student's" Test at $p \leq 0.05$ was used for the analysis of differences in body size. The coefficient of variation was calculated on the basis of values converted into length by $\mathrm{CV}=$ (standard deviation) $\mathrm{x}(100)$ /mean .

It has been clearly established under laboratorial conditions that the development of the immature stages of Ae. albopictus depends on food supply, density and temperature (Hawley', 1988 , Mori ${ }^{9}, 1979$ ). The first cited author recorded the Ae. albopictus larval development time as from 5 to 10 days at near $25^{\circ} \mathrm{C}$ temperature and food in optimum amounts. As the containers studied had abundant and scarce food supplies and differences in the rate of larval growth were expected on our study, as also in the correlation between amounts the food present and temperature as between the experiment. The immature overall development periods were 19.6, 27.3 and 37.5 days, under field condition (Table 1).

The variations in the duration of the larval and pupal development periods up to adult emergence increase with a decreasing amount of available food (the shortest and the longest periods occurred in the tree hole and in the tire Table 1). The tree hole microhabitat contained a sophrophytic fungus and decayed leaf litter; in the bamboo stump there were some organisms and the material decomposition of the inside of the wall, but in the water from the tire there was an apparent lack of food. Hotchnink ${ }^{7}$ (1985) showed the difference in 
Table 1. Duration of development in days from larva to emergent adult Aedes aibopictus under natural and artificial conditions.

\begin{tabular}{lcccccccccc}
\hline Container & $\begin{array}{c}\text { Total of } \\
\text { larvae }\end{array}$ & L1 & L2 & L3 & L4 & pupae & overall & males & fernales & $\%$ \\
\hline Tree hole & 80 & 4.5 & 3.4 & 4.3 & 7.9 & 7.7 & 19.6 & 22 & 30 & 65 \\
Bamboo & 83 & 3.5 & 3.3 & 5.4 & 14.0 & 14.3 & 27.3 & 39 & 15 & 65 \\
Tire & 90 & 4.0 & 8.0 & 9.2 & 21.0 & 13.5 & 37.5 & 17 & 20 & 41 \\
\hline
\end{tabular}

L = larva

the rate of larval growth of Ae, aegypti according to food types.

Larval stage had similar development times, except for the fourth-instar larvae. This stage presented the longest average intervals in days for all three experiments (Table 1). Thus if the larval growth periods were unequal depending on the respective breeding sites it suggests the influence of starvation in our experiments or this might be the reason for the difference in larval duration time as between the three experiments (Table 1).

The Ae. albopictus pupal development times lasted $7.7,14.3$ and 13.5 days in the tree hole, bamboo and tire, respectively (Table1). The pupation time was longer for the fourth-instar larvae and the overall development periods were clearly distinct among themselves, though, once again, it was longest in the tire. The average temperature was the same in the respective containers (mean of $22^{\circ} \mathrm{C}$ ). It has been shown $\left(\mathrm{PAHO}^{13}, 1989\right)$ that Ae. albopictus it took 3 days at $25^{\circ} \mathrm{C}$ and 5 days at $20^{\circ} \mathrm{C}$, so the present result is higher than PAHO'S and suggests that size of pupation may also be affected by the respective conditions of the breeding sites.

The mortality of the immature stages during mosquito growth is a very well-know fact and depends, among other factors, on food supply (Hawley ${ }^{6}, 1988$ ). In our study the mortality in the trec hole was very low and limited almost entirely to the first-instar and second-instar larvae (correlation coefficient $=0.61$ ). In the bamboo the mortalities in the third and fourth-instar larvae were higher than in the second-instar, with no mortality at all in the first-instar (correIation coefficient $=0.92$ ). The mortality curves under three diversified breeding conditions show an increase in the same as regards to the ages of individuals in the bamboo and tire, in which it is supposed that the amount of food was smaller than in the tree hole (Figures $\mathrm{A}, \mathrm{B}$ and $\mathrm{C}$ ). Hawley $^{6}$ (1988) recorded that development rate and size at pupation are highly sensitive to any decrease in food. Chan et al. ${ }^{2}$ (1971) showed that
Ae. albopictus has been shown to be able to survive under various microhabitat types with different concentrations of food and in an experimental field study the larval was shown to be of $80 \%$. Figure $\mathrm{C}$ shows a maximum mortality rate that percentage.

The larval and pupal mortalities are shown in Figures A, B and C and the pupal mortality seen to be higher in the bamboo and tire habitats than in the tree hole. The lack of food and the average temperature of $22^{\circ} \mathrm{C}$ may have had some influence on their mortality. Smith et al. ${ }^{14}$ (1988) established $46.1^{\circ} \mathrm{C}$ as the minimum temperature at which $100 \%$ mortality ocurred for all stages of Ae. albopictus.

The wing length measurement for females from each experimental rearing indicated a wide range of body size and a high degree of variation among the individuals from the three experiments (Table 2). In spite of the low numbers of adults, it seems that the mean size of emergent females of Ae. albopictus had decreased proportionally, according to the increasing degree of artificiality of the conditions under which they were reared. Table 2 shows that the wing length presented small variation among large females $(3.31 \mathrm{~mm} \pm 0.11 \mathrm{~mm})$ in the tree hole and among medium size females $(2.73 \mathrm{~mm} \pm 0.11 \mathrm{~mm})$ in the bamboo. A greater variation in wing length occurred among females from the tire $(2.48 \mathrm{~mm} \pm$ $0.20 \mathrm{~mm}$ ). A statistically significant variation ( $\mathrm{P}$ $<0.05$ ) occurred among them in this study (Table 3). Landry et al. ${ }^{8}$ (1988) demonstrated seasonal larval changes in the body size of Aedes triseriatus but our study occurred during the autumn season. only and there was an abundance of Ae, albopictus larvae in natural breeding sites. Thus, this factor could not greatly have influenced the result of our experiment. Ae. aegypti females emerging from fieid-collected pupae had an average wing length of $2.47 \mathrm{~mm} \pm 0.20 \mathrm{~mm}$ (Nasci $\left.{ }^{10}, 1986\right)$ and that of Ae.albopictus in the tire corresponded to $2.48 \mathrm{~mm}$, but in the tree hole it was of $3.31 \mathrm{~mm}$ (Table 2). Nasci $^{\text {th }}(1986)$ found a variance in adult body size 


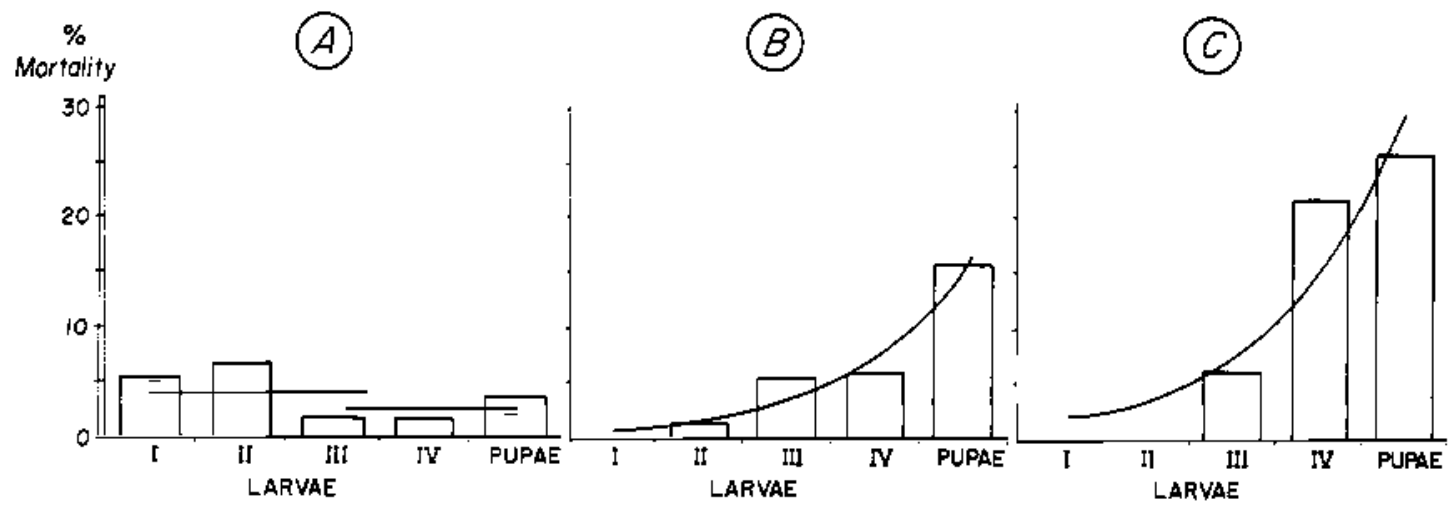

Figure. Mortality rates for the immature stages of $A \theta d e s$ albopictus from (A) tree hole, (B) bamboo stump and $(\mathrm{C})$ auto tire.

among species of mosquitoes using rapidly changing or ephemeral habitats. Chadee" (1993) found in cans an Ae. aegypti wing length smaller than that of Ae.aegypti emerging from drums. In our study the Ae, albopictus's largest body size was that from the tree hole $(1.92 \mathrm{~mm} \pm 0.16 \mathrm{~mm})$ and the greatest coefficient of variation of wing length was that from the tire $(8.06 \%)$, Table 2 .

The length of the hind femur was higher for females from the tree hole $(1.92 \mathrm{~mm})$ and the coefficient of variation was the smallest for females from the bamboo $(4.55 \%)$. The femurs of females from the tire were the shortest but the coefficient of variation was higher than the others (Table 2). Thus the hind femur length tended to change in accordance with the wing length females from bamboo and tire (Table 3 ).

The mosquito population is heterogeneous and the study of the relationship between body size and epidemiological significance involves different characteristics such as survival, parity, infective capacity and blood feeding success (Nasci \& Mitchel1'2, 1993; Nasci"', 1987; Landry et al. ${ }^{*}$ 1988). Our three experiments presented differences between the development period and body size variation, the smallest emergent females being those from the artificial container. Nasci \& Mitchell ${ }^{12}$ ( 1993) recorded that larger Ae. aegypti females were significantly more suscetible to infection by Ross River virus than the smaller ones. Thus it is supposed that many factors which could affect the Ae.albopictus's vectorial capacity may be present in towns.

\section{Acknowledgements}

We acknowledgements the collaboration of Dr. Maria Anice Mureb Sallum in the orientation

Table 2. Wing and hing femur length of Aodes albopictus females reared under three different conditions.

\begin{tabular}{lccccc}
\hline & & \multicolumn{2}{c}{ Mean lenght $(\mathrm{mm})$} & \multicolumn{2}{c}{ Coeficient of variation (\%) } \\
Container & $\begin{array}{c}\text { Females } \\
\text { number }\end{array}$ & Wing & Femur & Wing & Femur \\
\hline Tree hole & 25 & $3.31 \pm 0.11$ & $1.92 \pm 0.16$ & 3.32 & 8.33 \\
Bamboo & 12 & $2.73 \pm 0.11$ & $1.54 \pm 0.07$ & 4.03 & 4.55 \\
Tire & 19 & $2.48 \pm 0.20$ & $1.41 \pm 0.15$ & 8.06 & 10.64 \\
\hline
\end{tabular}

Table 3. Comparison of wing and femur lengths of female of Ae. albopictus reared under three different conditions. The values of the "Student's" test are followed by their probability.

\begin{tabular}{|c|c|c|c|c|}
\hline \multirow{2}{*}{ Breeding condition } & \multicolumn{2}{|c|}{ Wing } & \multicolumn{2}{|c|}{ Fernur } \\
\hline & "t" & $p$ & $" \mathrm{t} "$ & $p$ \\
\hline $\begin{array}{l}\text { Tree hole X Bamboo } \\
\text { Tree hole X Tire 15.333 } \\
\text { Bamboo X Tire17.311 } \\
\text { Tree hole X Bamboo + Tire }\end{array}$ & $\begin{array}{c}16.261 \\
p<0.001 \\
p<0.001 \\
4.588\end{array}$ & $\begin{array}{c}p<0.001 \\
10.001 \\
53.756 \\
p<0.001\end{array}$ & $\begin{array}{c}10.682 \\
p<0.001 \\
p<0.001 \\
3.300\end{array}$ & $p<0.001$ \\
\hline
\end{tabular}


on the measuring of wing length and hind femur, Aristides Fernandes, in the identification of immature forms and the technical staff of SUCEN (Taubaté County, S. Paulo) with their technical performance.

\section{References}

1. BRITO, M.; MARQUES, G. R. A. M.; MARQUES, C. C. A.; TUBAKI, R,M. Primeiro encontro de Aedes (stegomyia) albopictus (Skuse) no Estado de Săo Paulo (Brasil). Rev. Saúde Pública, 20:489, 1986.

2. CHAN, K. L.; HO, B. C.;CHAN, Y.C. Ae. aegypti (L.) and Ae. albopictus (Skuse) in Singapore city, 2- Larval habitats. Bull. World. Hith. Organ., 44: 629-33, 1971.

3. CHADEE, D. D. Size of emerging and host-seeking Ae. uegypt $i$ and the relationship to containers and bloodfeeding success in Trinidad, West Indies. Bull. Soc: Vector Control, 18: 105-8, 1993.

4. GOMES, A. de C.; FORATTINI, O. P.: KAKITANI, I.; MARQUES, G.R.A.M.;MARQUES, C. A.;MARUCCI, D.; BRITO, M. Micro-habitats de Ae. albopictus (Skuse) na regiăo do Vale do Paraíba, Estado de Săo Paulo, Brusil. Rev. Saúde Pública, 26: 108-18, 1992.

5. GOMES, A. de C.; MARQUES, G.R.A.M.; MARQUES, C.C.: SIMŌES, M.B.P.D. Estudo do hábito alimentar de Ae. albopictus no Estado de São Paulo.
[Resumo]. Rev, Bras. Parasitol. Vet., (Supl, I): 13, 1993 .

6. HAWLEY, W.A. The biology of Ae. albopictus. Am. Mosquito Control Assoc, 4: 2-39, 1988.

7. HOTCHKIN, P.G. The duration of larval life of Ae. aegypti as affected by time of hatch. Am. Mosquito Control Assoc, 1: 489-92, 1985.

8. LANDRY,S.V,;DEFOLIART, G.R. ; HOOG, D.B. The adul body size and survivorship in a field population of $A e$. triseriatus Am. Mosquito Control Assoc., 4: 121-8, 1988.

9. MORI, A. Effects of larval density and nutrition on some attribute of immature and adult Ae. albopictus. Trop. Med., 21: 85-103, 1979.

10. NASCI, R.S. The size of emerging and host-seeking Ae. aegypt $i$ and the relation of size to blood-feeding success in the field. Am. Mosquito Control Assoc., 2:61-2, 1986.

11.NASCI,R.S. Adult body size and parity in field populations of the mosquitoes Anopheles crucians, Aedes taeniorhyncus and Ae. sollicitans. Am. Mosquito Control Assoc, 3:636-7,1987.

12. NASCI,R.S. \& MITCHELL,C.J, Laryal diet, adult size and susceptibility of Aedes aegypti to infection with Ross River virus. Inf. Exch., (Jan):27-28, 1993.

13. PAN AMERICAN HEALTH ORGANIZATION. Executive Committee of the Directing Council. Ae. albopictus in the Americas; $99^{\text {th }}$ meeting. Washington D.C., 1987(CE99 15).

14.SMITH, G.C.; ELIASON, D.A.; MOORE, C.G.; IHENACHO, E.N. Use of elevated temperature to kill Aedes albopictus and Aedes aegypti. J. Am. Mosquito Control Assoc., 4:557-8, 1988.

\section{Resumo}

Ae. alboplctus foi criado em oco de árvore, intemódio de bambu e pneu de carro descartável, sob condiçōes de campo. O resultado obtido a partir de larvas recém-nascidas até alado fol de $19,6,27,3$ e 37,5 dias. As larvas dos três primeiros estádlos tiveram tempo de crescimento similar, năo obstante tratar-se de diferentes micro-habitats estudados. Confudo, larvas de $4^{2}$ estádio apresentaram tempo de duraçāo mais longo e crescente do oco de árvore para o pneu. A temperatura média dos trés micro-habitats variou de $18^{\circ} \mathrm{C}$ a $22^{\circ} \mathrm{C}$. O resultado da taxa de mortalidade encontrada fol menor para larva e pupa do oco de árvore e maior para o pneu. A medida do comprimento medio de asa das fêmeas emergidas do oco de árvore foi maior em relaça aquula do pneu.

Aedes, crescimento \& desenvolvimento. Asa, crescimento \& desenvolvimento. 